\title{
Terms, Definitions, Nomenclature, and Routes of Fluid Administration
}

\author{
Rosalind S. Chow* \\ Department of Veterinary Clinical Sciences, College of Veterinary Medicine, University of Minnesota, St. Paul, MI, \\ United States
}

Fluid therapy is administered to veterinary patients in order to improve hemodynamics, replace deficits, and maintain hydration. The gradual expansion of medical knowledge and research in this field has led to a proliferation of terms related to fluid products, fluid delivery and body fluid distribution. Consistency in the use of terminology enables precise and effective communication in clinical and research settings. This article provides an alphabetical glossary of important terms and common definitions in the human and veterinary literature. It also summarizes the common routes of fluid administration in small and large animal species.

\section{OPEN ACCESS}

Edited by:

William W. Muir,

Lincoln Memorial University,

United States

Reviewed by:

Nathan Peterson,

VCA West Los Angeles Animal

Hospital, United States

Dennis Chew

The Ohio State University,

United States

*Correspondence:

Rosalind S. Chow

rchow@umn.edu

Specialty section:

This article was submitted to Comparative and Clinical Medicine,

a section of the journal

Frontiers in Veterinary Science

Received: 04 August 2020

Accepted: 02 December 2020

Published: 15 January 2021

Citation:

Chow RS (2021) Terms, Definitions, Nomenclature, and Routes of Fluid Administration.

Front. Vet. Sci. 7:591218.

doi: 10.3389/fvets.2020.591218
Keywords: intraosseous, subcutaneous, intravenous, terminology, rehydration, fluid therapy, glossary, fluid administration methods

\section{INTRODUCTION}

Fluid therapy is an important component in the treatment of many hospitalized veterinary patients. The breadth of literature on fluid therapy-related concepts and management strategies is continually expanding and clarity in the use of the terminology is essential for effective communication and patient care. Using incorrect terms can lead to misunderstanding, misinterpretations, and inappropriate therapeutic decisions. The first aim of this article is to provide a glossary of key terms with reference to definitions found in the veterinary and human medical literature. Commonly used abbreviations, synonyms, and related words are listed after the associated term, where applicable. An expanded definition is provided for any term for which there is no widely accepted definition. The second aim of this article is to describe the different routes of fluid administration in veterinary species.

\section{METHODS}

For the glossary, a list of fluid therapy related terms was compiled based on common terms encountered in the fluid therapy literature pertaining to intravenous fluid classifications, intravenous fluid administration strategies, body fluid volume and hydration, body fluid compartments, body fluid composition, and acid-base balance. A systematic PubMed/MEDLINE search and literature review of the veterinary and human medical literature was performed between January to October 2020 to search for individual terms in the title, key words or abstract. The full glossary term was used as the search term by itself, individually as well as with the addition of the following words: "definition," "veterinary," and if needed, included terms denoting to specific veterinary species such as "dog," "cat," or "horse.". For example, the search strategy for "Acute Normovolemic Hemodilution" used the following search terms: "acute normovolemic hemodilution," "acute normovolemic hemodilution definition," "acute normovolemic hemodilution veterinary," "acute normovolemic hemodilution dog" and "acute 
normovolemic hemodilution cat." Publications were considered if they were available in English and were published or in press. A minimum of 3 articles were reviewed for each search term, up to a maximum of 6 articles. Priority was given to articles from journals with a high impact factor, veterinary journals, and consensus-type articles, as well as the most recently published definitions. Case reports, comments, editorials and letters to the editor were excluded because they rarely contained definitions. The full text of all identified articles were screened for definitions to one or more glossary terms and multiple articles were evaluated in order to determine the degree of agreement. If the literature search revealed inconsistencies in the definition for any particular term, the literature search was expanded, and the most commonly encountered definition was provided with the addition of a notation mentioning the lack of widespread consensus. Where multiple similar terms could be used describe the same concept, the most frequently encountered term was listed in the glossary and synonyms were provided at the end of the applicable definition.

\section{RESULTS}

\section{Glossary of Terms Absolute Hypovolemia}

A reduction in total circulating blood volume. Absolute hypovolemia can be caused by dehydration (i.e., water and electrolyte loss) or the loss of blood from the body or into a body cavity (e.g., abdomen) $(1,2)$.

\section{Acid}

A substance that is capable of increasing the concentration of hydrogen ions $\left(\mathrm{H}^{+}\right)$when dissolved in water (aqueous solution) (3).

\section{Acidemia}

A blood $\mathrm{pH}$ that is below the normal physiologic range for the species in question (4).

\section{Acidosis}

A process in which there is a net accumulation of acid in the body (3).

\section{Acute Normovolemic Hemodilution}

A blood conservation strategy where a specific volume of whole blood is removed from the patient and stored, and replaced by sufficient volumes of crystalloid or colloid solutions to restore intravascular volume prior to surgery. The rationale of this technique is to reduce the loss of red blood cells from surgical bleeding through hemodilution, thereby lowering the need for allogenic blood transfusions. The reserved blood is subsequently returned to the patient during or after surgery (5). Synonym: isovolemic hemodilution.

\section{Albumin}

Circulating blood protein weighing $69 \mathrm{kDa}$ that is synthesized by the liver and is the major determinant of plasma oncotic pressure (6).
Alkalemia

A blood $\mathrm{pH}$ that is above the normal physiologic range for the species in question (4).

\section{Alkalosis}

A process in which there is a net accumulation of alkali in the body (7).

\section{Anion}

A negatively charged atom or molecule, such as chloride $\left(\mathrm{Cl}^{-}\right)$ and bicarbonate $\left(\mathrm{HCO}^{-}\right)$(8).

\section{Anion Gap (AG)}

The calculated difference between the principle cations and anions in plasma. Anion gap is calculated by the following formula: $\mathrm{AG}=\left(\mathrm{Na}^{+}+\mathrm{K}^{+}\right)-\left(\mathrm{Cl}^{-}+\mathrm{HCO}^{-}\right)$. Anion gap is useful to help narrow down the potential causes of metabolic acidosis $(4,8)$.

\section{Autotransfusion}

A blood conservation strategy used during hemorrhage or surgery where shed blood is collected, typically mixed with anticoagulant, filtered and reinfused into the patient (9). In human medicine, where it is typical to wash red blood cells prior to readministration, this process is also referred to as blood salvage or cell salvage.

\section{Balanced Component Resuscitation}

A fluid resuscitation strategy in severe trauma management where blood products are transfused in proportions similar to blood (1:1:1 ratio for packed red blood cells, plasma and platelets) $(10,11)$. Synonym: balanced resuscitation.

\section{Balanced Crystalloid Solution}

A fluid that contains an electrolyte composition (particularly sodium, potassium, and chloride) that is similar to that found in plasma. A balanced solution should maintain or normalize acid-base balance and be isosmotic and isotonic (i.e., not induce inappropriate fluid shifts) with normal plasma (4, 12, 13). Synonyms: balanced isotonic electrolyte solution, polyionic crystalloid solution, or balanced salt solution.

\section{Base}

A substance that is capable of accepting a hydrogen ion $\left(\mathrm{H}^{+}\right)$ when dissolved in water (3).

\section{Base Deficit}

The amount of a strong base that must be added in vitro to $1 \mathrm{~L}$ of oxygenated blood to return the $\mathrm{pH}$ to 7.40 , at a partial pressure of carbon dioxide of $40 \mathrm{mmHg}$, and temperature of $37^{\circ} \mathrm{C}$, in the presence of metabolic acidosis (14). Represents a deficiency of base, or the negative form of base excess, where a $\mathrm{BD}$ of +1 $\mathrm{mmol} / \mathrm{L}$ is equivalent to a $\mathrm{BE}$ of $-1 \mathrm{mmol} / \mathrm{L}$.

\section{Base Excess}

The amount of a strong acid in $\mathrm{mmol} / \mathrm{L}$ that must be added in vitro to $1 \mathrm{~L}$ of oxygenated blood to return the $\mathrm{pH}$ to 7.40 , at a partial pressure of carbon dioxide of $40 \mathrm{mmHg}$, and temperature 
of $37^{\circ} \mathrm{C}$, in the presence of metabolic alkalosis (14). See also standard base excess.

\section{Blood Volume}

The total volume of blood contained within the circulatory system (15). Synonym: vascular volume, intravascular volume.

\section{Buffered Crystalloid Solution}

An intravenous fluid containing an acid-base buffer in order to help maintain or restore physiologic $\mathrm{pH}$. This consists of an aqueous solution containing a mixture of electrolytes and a weak acid and its conjugate base. The most common buffers are bicarbonate or organic anions (e.g., lactate, acetate, gluconate) (4).

\section{Cation}

A positively charged atom (e.g., $\mathrm{Na}^{+}, \mathrm{K}^{+}, \mathrm{Ca}^{2+}$ ) or molecule $\left(\mathrm{NH}_{4}^{+}\right)(7,8)$.

\section{Cell Salvage}

See autotransfusion.

\section{Central Venous Pressure (CVP)}

Measurement of venous blood pressure within a large central vein, or more specifically, the cranial or caudal vena cava (16). A controversial method of assessing right ventricular preload, CVP is not correlated with total blood volume and it is not a good general predictor of fluid responsiveness $(17,18)$.

\section{Colligative Properties}

Alterations in the properties of a solvent due to the addition of solutes. Colligative properties depend on the concentration of molecules in solution, rather than the type of chemical species present $(19,20)$. Examples include vapor pressure, boiling point, freezing point, and osmotic pressure.

\section{Colloid}

Large molecular weight molecules $(>30 \mathrm{kDa})$ that are preferentially retained in the intravascular space following intravenous administration. Types of natural colloids include plasma and albumin. Synthetic colloids include hydroxyethyl starches, dextrans, and gelatins $(7,21)$.

\section{Colloid Osmotic Pressure}

The osmotic force generated by large molecules (colloids) in solution when separated by a semipermeable membrane from a region with a different colloid concentration (22). The colloid osmotic pressure provided by plasma proteins is also referred to as oncotic pressure.

\section{Colloid Solution}

An intravenous fluid containing macromolecules dispersed in a crystalloid solution. It is administered to support intravascular volume or raise plasma colloid osmotic pressure (23-25). Natural colloid solutions include blood products and albumin. Synthetic (or artificial) colloid solutions include hydroxyethyl starches, dextrans and gelatins. Colloid fluid therapy is also referred to as biophysical therapy (26).

\section{Constant Rate Infusion (CRI)}

Continuous intravenous administration of a medication in order to maintain a steady delivery or plasma concentration (27).

\section{Critical Hematocrit}

The minimum hematocrit that supports adequate tissue oxygenation and below which organ ischemia will develop $(28,29)$.

\section{Crystalloid}

A solution that contains electrolytes and other small water soluble molecules, and/or dextrose. Crystalloids are categorized by their tonicity relative to plasma: isotonic, hypotonic, and hypertonic (23-25).

\section{Cumulative Fluid Balance}

The difference between all fluid inputs and outputs over a defined period of time $(30,31)$. Cumulative fluid balance over a $24-\mathrm{h}$ period is also referred to as daily fluid balance.

\section{Daily Fluid Balance}

The difference between all fluids inputs and outputs during a 24$\mathrm{h}$ period, generally excluding insensible losses $(30,31)$. Daily fluid balance can be negative, neutral or positive.

\section{Damage Control Resuscitation}

A resuscitation strategy used to treat severely traumatized patients in order to reduce the development of the "lethal triad" of hypothermia, coagulopathy and acidosis $(32,33)$. The key principles are the early use of blood products, avoidance of excessive crystalloid infusions which can cause dilutional coagulopathy, and permissive hypotension $(32,33)$.

\section{Deescalation}

Reduction of fluid administration due to clinical improvement of the patient (31).

\section{Dehydration}

The loss of body water, with or without salt, at a rate greater than the body can replace it (34-36).

\section{Deresuscitation}

Correcting fluid overload by using dialysis or diuretics to remove excess fluid $(37,38)$.

\section{Early Goal-Directed Therapy}

A protocol-driven treatment algorithm that aims to guide fluid, vasopressor, and other resuscitation therapy toward specific hemodynamic end-points, with the goal of optimizing oxygen delivery $(24,39)$. Originally developed for the treatment of patients with sepsis (39), the concept has since been adopted for the treatment of critically ill patients with other conditions as well as in perioperative settings (40). "Early" refers to its use during the initial stabilization period, otherwise it is described as goal-directed hemodynamic therapy. 


\section{Edema}

Clinical manifestation of fluid accumulation within the interstitial tissue space (interstitial edema) or within cells (cellular edema) $(41,42)$.

\section{Effective Osmole}

An electrolyte (ion) that exerts an osmotic force (i.e., pull) across a semi-permeable membrane. Effective osmoles determine a solution's tonicity. Sodium ion is the predominant effective osmole in the body (43).

\section{Electrolyte}

Dissolved ions in solution that carry a positive or negative electric charge, such as sodium, potassium, chloride, and calcium (35).

\section{Endothelial Glycocalyx (EG)}

A negatively charged, mesh-like layer on the luminal surface of vascular endothelial cells, composed of membrane-bound glycoproteins and proteoglycans, which have an important role in regulating vascular permeability, endothelial anticoagulation and modulating interactions between the endothelium and the vascular environment $(9,44-46)$. EG damage and breakdown are particularly susceptible to fluid overload, catecholamine-induced damage and shock (46).

\section{Euvolemia}

Normal circulating blood volume $(35,47)$.

\section{Fluid Administration}

Delivery of fluids to a patient through an enteral or parenteral route (48). The rate of fluid administration should be described in $\mathrm{ml} / \mathrm{kg} / \mathrm{min}$ or $\mathrm{ml} / \mathrm{kg} / \mathrm{h}$. Fluid rates described in $\mathrm{ml} / \mathrm{h}$ or $\mathrm{ml} / \mathrm{min}$ are meaningless unless they are referenced to body weight or body surface area. The duration of infusion should be stated in order to determine the total volume of fluid administered.

\section{Fluid Balance}

The net difference between bodily fluid gains or inputs (including enteral, subcutaneous and intravenous fluids, injectable medications, and blood products) and fluid losses or outputs (including urinary, gastrointestinal, blood losses) over a specified time period $(49,50)$. Insensible losses are usually omitted (30). Fluid gains exceeding fluid losses represents a positive fluid balance, whereas fluid losses exceeding gains lead to a negative fluid balance. Fluid balance can be expressed as a volume or as a percentage of body weight. Related terms: daily fluid balance, cumulative fluid balance.

\section{Fluid Bolus}

Rapid intravenous administration of a small or large volume of fluid for the purpose of restoring tissue perfusion, such as during the treatment of hypovolemic shock $(31,51-53)$.

\section{Fluid Challenge}

Rapid intravenous administration of a modest volume of fluid, usually a crystalloid, in order to assess the likelihood of volumeresponsiveness in a patient with hemodynamic instability, while minimizing the risk of fluid overload $(31,54)$. A fluid challenge is typically followed by a fluid bolus in patients that exhibit a positive response to the fluid challenge.

\section{Fluid Compartments}

Describes the distribution pattern of total body fluid within several well-defined spaces separated from each other by cell membranes (55). Together, the intravascular and interstitial fluid compartments comprise the extra-cellular fluid space and contain approximately one-third of the total body water, while intracellular fluid compartment contains approximately twothirds of the total body water (55).

\section{Fluid Creep}

This term has two different situation-dependent meanings. Fluid creep describes the administration of IV fluid to burn patients in excess of fluid requirements calculated by the Parkland Formula $(56,57)$. This is done in an effort to optimize hemodynamic status but may increase the risk of edema formation. Fluid creep also refers to the unintentional and unmeasured fluid volumes administered in the process of delivering medication and nutrition through enteral and parenteral routes during maintenance fluid therapy or undocumented oral fluid intake (58).

\section{Fluid Infusion}

Intravenous fluid administration (31).

\section{Fluid Overload}

An increase in total body fluid (typically both water and electrolytes) in excess of physiologic requirements. Some publications define it as a $10 \%$ or more increase in total body weight due to fluid administration which represents the threshold for an increased risk of adverse clinical effects such as pulmonary edema, peripheral edema or body cavity effusion $(30,31,59-$ $61)$. This non-specific term is loosely used and in some cases may be replaced by more specific concepts, such as volume overload, which refers to excess fluid in the intravascular fluid compartment, or overhydration, which describes excessive pure water gain in the body.

\section{Fluid Responsiveness}

The ability for hemodynamic parameters to improve in response to a fluid challenge or bolus $(51,62)$. There is some variability in the specific parameters and magnitude of change that are considered consistent with a positive response. However, many definitions consolidate around an increase in cardiac output $(51,62)$ or stroke volume $(52,54)$ by at least $10-15 \%$ from baseline following administration of a fluid bolus that is delivered over $<15(51,52)$ or $30 \mathrm{~min}(53)$. Others consider a patient to be fluid responsive if there is a significant change in one or more of the following: increase in mean arterial pressure of more than $10 \mathrm{~mm} \mathrm{Hg}$, decrease in heart rate of more than $10 \mathrm{BPM}$, increase in central venous pressure $\left(>2 \mathrm{~cm} \mathrm{H}_{2} \mathrm{O}\right)$ or an increase urine output $(53,63)$. 


\section{Fluid Resuscitation}

The administration of intravenous fluids to reverse lifethreatening tissue hypoperfusion (31, 62). Synonym: volume resuscitation.

\section{Fluid Retention}

An increase in net fluid balance resulting accumulation of excess fluids in body tissues and weight gain (64-66) and in some cases, peripheral edema (66). This is due to physiological or pathological processes promoting renal reabsorption and fluid conservation, such as during dehydration, pregnancy, anesthesia, acute kidney injury (AKI) and congestive heart failure (64).

\section{Fluid Therapy}

The unnatural process of administering fluids as a treatment or preventative measure to maintain or restore normal body fluid balance.

\section{Fluid Titration}

Adjustment of intravenous fluid administration choice, rate, volume and timing in order to improve hemodynamics and optimize tissue perfusion (31).

\section{Fluid Underload}

Decrease in total body fluid, resulting in fluid deficit of the extracellular and/or intracellular fluid (67). The opposite of fluid overload.

\section{Goal-Directed Therapy (GDT)}

The use of advanced non-invasive and invasive monitoring techniques in conjunction with intravenous fluids, vasopressors or inotropes with the goal of maintaining or establishing hemodynamic stability, adequate tissue perfusion and oxygen delivery to tissues $(68,69)$.

See early goal-directed therapy.

\section{Hemodynamic Coherence}

Coherence between macrocirculatory and microcirculatory hemodynamics such that regional and microcirculatory perfusion and tissue oxygen delivery permits normal cellular function in support of organ function $(70,71)$.

\section{Hemoglobin-Based Oxygen Carrier (HBOC)}

A cell-free hemoglobin solution used in veterinary medicine in the 1990's and 2000's as a blood transfusion substitute to improve oxygen carrying capacity (72-74). HBOC's solutions are not commercially available in the US. Synonym: oxygen therapeutics.

\section{Hyperchloremic Metabolic Acidosis}

Hyperchloremia accompanied by hypobicarbonatemia and metabolic acidosis. Two different mechanistic explanations are bicarbonate loss or dilution (Henderson-Hasselbalch approach) (13) or a decrease in SID caused by an increase in chloride (i.e., $\left.0.9 \% \mathrm{Na}^{+} \mathrm{Cl}^{-}\right)(4,13,75)$. Synonym: normal anion gap acidosis.

\section{Hyperoncotic Colloid}

A colloid solution with an oncotic pressure above that of plasma (e.g., 10\% hydroxyethyl starch, 20\% human albumin) (76).

\section{Hyperperfusion}

Increased (supraphysiologic) blood flow to the tissues (35).

\section{Hypertonic Crystalloid}

A crystalloid solution with a higher effective osmolality than plasma (e.g., 7.2\% sodium chloride: $2464 \mathrm{mOsm} / \mathrm{L}$ ) (23).

\section{Hypertonic Saline (HS)}

A sterile hypertonic intravenous crystalloid composed of water, sodium and chloride. Available in multiple concentrations including $3 \%, 5 \%$ and $7.2 \%(77,78)$.

\section{Hypertonic-Hyperoncotic Solution}

A resuscitation fluid containing a hypertonic crystalloid ( $>310$ mosmol) and a hyperoncotic ( $>5 \%)$ colloid that is used as an alternative small volume fluid resuscitation strategy to rapidly increase intravascular fluid volume in the treatment of hypovolemia [e.g., 7.5\% saline and 6\% Dextran-70 (HSD)] (79, 80). Synonym: turbostarch.

\section{Hypervolemia}

Excessive circulating blood volume $(52,61)$. See also fluid overload.

\section{Hypooncotic Colloid}

A colloid solution with an oncotic pressure below that of plasma (e.g., $4 \%$ human albumin) (76).

\section{Hypoperfusion}

Insufficient blood flow to the tissues, resulting in decreased oxygen delivery. End-organ hypoperfusion can manifest as cool extremities, reduced pulse quality, oliguria and tachycardia (81, 82).

\section{Hypotensive Resuscitation}

See permissive hypotension.

\section{Hypotonic Crystalloid}

A crystalloid solution with a lower effective osmolality than plasma (e.g. $0.45 \%$ sodium chloride: $154 \mathrm{mOsm} / \mathrm{L}$ ) (23). A solution of $5 \%$ dextrose in water is also classified as a hypotonic fluid despite having an osmolality $(278 \mathrm{mOsm} / \mathrm{L})$ that is similar to plasma, since the dextrose is rapidly taken up into cells and metabolized following infusion, leaving water behind (48).

\section{Hypovolemia}

Insufficient intravascular fluid volume, which may be absolute such as from dehydration and hemorrhage, or relative such as with vasodilatory shock $(61,83)$.

\section{Ineffective Osmoles}

Small dissolved particles in solution that contribute to total osmolality but do not exert an osmotic pressure because they freely cross and equilibrate across cell membranes (e.g., urea, dextrose) (84). 


\section{Insensible Water Loss}

Body fluid losses that cannot be easily measured, such as evaporative losses from the skin and respiratory tract, and the water content of stool $(85,86)$.

\section{Interstitial Fluid}

The total volume of extracellular fluid contained within the interstitial tissues surrounding cells $(12-15 \%$ of total body weight) (55).

\section{Intracellular Fluid}

The total volume of fluid contained within cells (40\% of total body weight) (55).

\section{Intravascular Fluid}

The total volume of extracellular fluid contained within arteries, veins and capillaries in the circulatory system (6-8\% of total body weight) (55).

\section{Intravascular Volume Depletion}

Reduction in intravascular fluid volume, which is a type of extracellular fluid volume depletion (87). Related term: volume depletion.

\section{Isooncotic Colloid}

A colloid solution with an oncotic pressure similar to that of plasma (e.g., 6\% hydroxyethyl starch, 5\% human albumin) (88).

\section{Isotonic Crystalloid}

A crystalloid solution with an osmolality similar to plasma. The two types of isotonic crystalloids are isotonic saline $(0.9 \%$ sodium chloride) and balanced solutions (e.g., lactated Ringer's, Normosol ${ }^{\circledR}$-R) (13).

\section{Isovolemic Hemodilution}

See acute normovolemic hemodilution.

\section{Lactic Acidosis}

Hyperlactatemia with concurrent metabolic acidosis (89-93). Lactate is produced by skeletal muscle and other tissues in large amounts during anaerobic conditions and is commonly used as a marker of the adequacy of tissue perfusion (Type A lactic acidosis). Increased production of L-lactic acid in the absence of hypoxia or increased demand for ATP is termed Type B lactic acidosis. Notably, rapid intravenous administration of lactated Ringer's solution increases plasma lactate concentration within $10 \mathrm{~min}$ but baseline values are reestablished within $60 \mathrm{~min}$ after cessation of administration (93).

\section{Lean Body Mass}

Total body weight minus the weight of fat. Calculated as $80 \%$ of ideal body weight when $20 \%$ of total body weight is fat (94).

\section{Liberal vs. Restrictive Fluid Therapy}

Term applied to randomized trials investigating the effect on morbidity and mortality of a conservative (restrictive) fluid strategy, compared to a standard (liberal) fluid regimen. Many standard fluid regimens are more likely to result in a positive fluid balance (95-97).

\section{Macrocirculation}

Large and medium-sized arteries and veins that serve as conduit vessels, transporting blood to and from organs and tissues (98).

\section{Maintenance Fluid}

A type of crystalloid solution that is designed to maintain hydration by meeting daily water and electrolyte requirements $(7,23,86)$. Both hypotonic and isotonic fluids can fulfill these requirements (86).

\section{Maintenance Fluid Therapy}

A fluid therapy plan designed to provide water and electrolytes in quantities that meet normal daily fluid needs and replace urinary, gastrointestinal, and evaporative losses (86).

\section{Massive Hemorrhage}

Loss of $>40-50 \%$ of total blood volume over $3 \mathrm{~h}$ or less, or $>$ $100 \%$ of total blood volume over $24 \mathrm{~h}$ (99).

\section{Massive Transfusion}

Replacement of $>40-50 \%$ of total blood volume over $3 \mathrm{~h}(11,99)$, or $>100 \%$ of total blood volume over $24 \mathrm{~h}(100,101)$.

\section{Microcirculation}

Blood vessels $<200-300$ micrometers in diameter, consisting of small arteries, arterioles, capillaries, and venules (98, 102-104).

\section{Normal Anion Gap Metabolic Acidosis}

See Hyperchloremic metabolic acidosis.

\section{Normal Saline (NS)}

See isotonic saline.

\section{Normovolemia}

See euvolemia.

\section{Oncotic Pressure}

See colloid osmotic pressure.

\section{Osmolality}

A measure of the concentration of osmotically active particles per unit volume of solution, measured in milliosmoles per liter of solution $(\mathrm{mOsm} / \mathrm{L})(7,22,105)$. In clinical practice, osmolarity, and osmolality are similar enough to be used interchangeably (106).

\section{Osmolarity}

A measure of the concentration of osmotically active particles per unit mass of solution, measured in milliosmoles per kilogram of solution $(\mathrm{mOsm} / \mathrm{kg})(7,22,105)$. In clinical practice, osmolarity, and osmolality are similar enough to be used interchangeably (106).

\section{Osmosis}

The process by which molecules of a solvent tend to pass through a semipermeable membrane from a less concentrated solution into a more concentrated solution, thus equalizing the concentrations on both sides of the membrane (20). 


\section{Parenteral}

Administration of food or medication through a non-enteral (e.g., non-oral) route, such as intravenous, subcutaneous, intramuscular and intradermal (107).

\section{Parkland Formula}

A fluid resuscitation protocol for burn patients which calls for lactated Ringer's solution dosed at $4 \mathrm{ml} / \mathrm{kg} / \%$ TBSA, where \%TBSA refers to the percentage of the total body surface area burned $(108,109)$. Half of the volume is delivered over the first $8 \mathrm{~h}$ and the remainder over the next $16 \mathrm{~h}$.

\section{Perfusion}

The passage of fluid through the circulatory system to organs and tissues $(103,110)$.

\section{Permissive Hypotension}

A fluid therapy technique that aims to provide enough resuscitation fluid to ensure adequate end-organ perfusion while maintaining mild hypotension (systolic pressures $<90 \mathrm{mmHg}$ ) until definitive hemorrhage control can be achieved $(32,33,111)$. Synonym: hypotensive resuscitation.

\section{Plasma}

The liquid portion of blood that remains after the cells are removed. Plasma is retrieved by centrifugation of an anticoagulated blood sample, and so unlike serum, it contains fibrinogen and clotting factors (112).

\section{Pleth Variability Index (PVI)}

An automatic measure of the dynamic change in perfusion index (PI), as determined by a pulse oximeter, occuring during a complete respiratory cycle. The pulse oximeter derived pulsatile signal is indexed against the non-pulsatile infrared signal and expressed as a percentage $[\mathrm{PI}=(\mathrm{AC} / \mathrm{DC}) \times 100]$ reflecting the amplitude of the pulse oximeter waveform. The pulse variability index is calculated as PVI $=[(\mathrm{PImax}-\mathrm{PImin}) / \mathrm{PImax}] \times$ 100 (113).

\section{Polyionic Crystalloid Solution}

See balanced crystalloid solution.

\section{Proteid}

A complex biomolecule predominantly made of polypeptides that is found in all living matter (114).

\section{Pulse Pressure (PP)}

The difference between arterial systolic and diastolic blood pressure measured in millimeters of mercury (mm Hg) (115).

\section{Pulse Pressure Variation (PPV)}

The difference between the maximum (PPmax) and minimum (PPmin) arterial pulse pressures during one respiratory cycle, divided by their sum divided by 2 ([PPmax + PPmin $] / 2)$ and expressed as a percentage (116). Pulse pressure variation is used as a predictor of fluid responsiveness in mechanically ventilated patients.

\section{Pulse Wave Transit Time (PWTT)}

Time needed for a pulse wave to travel between two arterial sites (117). Due to its inverse relationship to stroke volume, it can be used to assess changes in cardiac output and to evaluate fluid responsiveness in dogs after a fluid challenge (117). It also serves as a marker of arterial stiffness in humans with coronary artery disease (118). PWTT can be calculated as the time from the peak of the R-wave on an electrocardiogram to the rise point of the pulse oximeter wave (the point where it attains $30 \%$ of its maximal amplitude) (119).

\section{Rebound Hypovolemia}

Hypovolemia produced by diuresis induced by rapid bolus fluid administration to conscious animals (120).

\section{Relative Hypovolemia}

A reduction in the effective circulating blood volume due to venodilation and increased venous capacitance (2). Relative hypovolemia can be caused by drug toxicity (e.g., sensitivity to anesthetic drugs or anesthetic overdose), impairment or loss of compensatory mechanisms, coexisting or induced metabolic or respiratory acidosis, traumatic or surgically induced inflammation, sepsis, cardiogenic shock, and hypothermia.

\section{Replacement Fluid}

A type of crystalloid solution that is isotonic, has a composition similar to extracellular fluid, and is administered to replace water and electrolyte losses (e.g., Normosol-R, lactated Ringer's, Plasma-Lyte 148) (7, 23).

\section{Rescue, Optimization, Stabilization, and Evacuation (ROSE)}

A conceptual framework that describes four different stages of fluid resuscitation, beginning with initial rapid fluid administration to treat life-threatening shock (Rescue), continued fluid therapy until adequate perfusion is restored (Optimization), followed by ongoing maintenance fluids (Stabilization), and gradual discontinuation of fluid support (i.e., Evacuation or De-escalation) $(31,109,121)$.

\section{Resuscitation}

See fluid resuscitation.

\section{Revised Starling Equation}

An updated version of the traditional Starling equation that incorporates current understanding of the role of the endothelial glycocalyx in transvascular fluid filtration $(44,122,123)$. Related term: Starling Principle.

\section{Sensible Water Loss}

Measurable body fluid losses, such as urine, vomit, and diarrhea $(85,86)$.

\section{Shock}

A life-threatening, generalized form of acute circulatory failure associated with inadequate oxygen utilization by the cells, resulting in cellular dysfunction (124). Shock is most commonly organized into four major classifications that have different pathophysiological mechanisms: hypovolemic shock refers to reduced effective circulating volume, from internal 
or external intravascular fluid loss (125); obstructive shock results from physical impairment to blood flow, such as from thromboembolic disease; distributive shock is caused by maldistribution of blood flow due to loss of vasomotor tone, such as during sepsis or anaphylaxis (124); cardiogenic shock describes cardiac pump dysfunction resulting in decreased forward flow $(124,126)$.

\section{Shock Index (SI)}

Calculated as the ratio of the heart rate (HR) divided by systolic blood pressure (SBP) (127). SI >1.0 is a predictor of increased risk of mortality and other markers of morbidity (128).

\section{Skin Turgor}

The relative elasticity of the skin, used as an estimate of hydration status $(129,130)$. Skin turgor is evaluated by tenting the skin with the fingers and timing its return to its normal form. Dehydration and increasing age are associated with decreased skin turgor (34).

\section{Standard Base Excess (SBE)}

The amount of strong acid (millimoles per liter) that needs to be added in vitro to $1 \mathrm{~L}$ of fully oxygenated whole blood to return the sample to standard conditions ( $\mathrm{pH}$ of $7.40, \mathrm{PCO}_{2}$ of $40 \mathrm{~mm}$ $\mathrm{Hg}$, and temperature of $37^{\circ} \mathrm{C}$ ), at a hemoglobin concentration of $\sim 50 \mathrm{~g} / \mathrm{L}(14,131)$. Unlike base excess, standard base excess has been adjusted to reflect the extracellular fluid buffering capacity of hemoglobin in vivo. It is used clinically to determine the degree of metabolic acidosis.

Synonym: base excess of the extracellular fluid $\left(B E_{E c f}\right)$. Related term: base excess.

\section{Starling Principle}

Fluid flux across the capillary wall is determined by a balance of hydrostatic and oncotic pressures such that fluid leaves the capillary at the arterial end of the capillary and is absorbed at the venous end of capillary (123).

\section{Stressed Vascular Volume (Vs)}

The volume of blood within a vein that produces a transmural pressure above zero $(52,132)$. Compare to unstressed vascular volume.

\section{Stroke Volume Variation (SVV)}

The difference between maximum and minimum stroke volume during one respiratory cycle, divided by their mean, and averaged over several breaths (133). Stroke volume variation is used as an indicator of fluid responsiveness in mechanically ventilated patients.

\section{Strong lon}

A cation and anion that are considered to be fully dissociated at physiologic $\mathrm{pH}(13,131,134,135)$. The major strong cations in plasma are sodium, calcium and magnesium, while the major strong anions are chloride, sulfate, and lactate.

\section{Strong lon Difference (SID)}

The difference between the concentrations of strong cations and strong anions in plasma (134-136).

\section{Strong lon Gap (SIG)}

SIG quantifies [unmeasured anions] - [unmeasured cations] of both strong and weak ions. It is reflects the difference between the activity of all common cations $\left(\mathrm{Na}^{+}, \mathrm{K}^{+}, \mathrm{Mg}^{2+}, \mathrm{Ca}^{2+}\right)$ with the common anions $\left(\mathrm{Cl}^{-}\right.$, lactate, urate) and other measured nonvolatile weak acids $\left(\mathrm{A}^{-}\right)$. SIG is calculated as SIDa - SIDe, or more specifically, as $\left[\mathrm{Na}^{+}\right]+\left[\mathrm{K}^{+}\right]+\left[\mathrm{Mg}^{2+}\right]+\left[\mathrm{Ca}^{2+}\right]-\left[\mathrm{Cl}^{-}\right.$ corrected $]-[$ lactate $]-\left[\mathrm{A}^{-}\right]-\left[\mathrm{HCO}_{3}^{-}\right]$, in milliequivalents per liter; where SIDa is the apparent strong ion difference and SIDe is the effective strong ion difference (137). An increased SIG is a predictor of mortality (8).

\section{Third Spacing}

The pathological shift of fluid into extracellular sites in the body that are anatomically separated from other body fluid compartments and where the fluid is considered to have no physiological function (138-140). In human patients, the fluid movement is theorized to occur following trauma or major surgery into ill-defined spaces following intravenous fluid administration. However, these "spaces" have since been identified to include interstitial fluids. Third space fluids are eventually reabsorbed into the central fluid compartment and are therefore considered to be a myth $(139,140)$. In veterinary medicine, the term is also used to refer to the loss of fluids into body cavities, such as the pleural space, peritoneal space and gastrointestinal lumen (141).

\section{Titration}

See fluid titration.

\section{Tonicity}

A measurement of the effective osmolality of a solution, which corresponds to its ability to cause water to diffuse across a semipermeable membrane, such as the cell membrane $(20,142-144)$. A cell will swell when placed in a hypotonic solution, shrink when placed in a hypertonic solution, and have an unchanged volume in an isotonic solution.

\section{Total Body Water}

The total water content in the body, which represents the sum of the intracellular and extracellular fluid volumes $(43,52)$. Total body water is $\sim 60 \%$ of ideal body weight in adult dogs (55), cats (55), and horses (145).

\section{Unstressed Vascular Volume (Vu)}

The volume of blood in a vein that produces a transmural pressure equal to zero $(52,132)$. The sum of the stressed $(\sim 30 \%$ of total volume) and unstressed ( $\sim 70 \%$ of total volume) volumes is the total blood volume within the venous system (132). Compare to stressed vascular volume.

\section{Vascular Hyporesponsiveness}

A decreased vascular response to fluid therapy or the pressor effects of exogenous vasopressors (146). Vascular reactivity to the administration of catecholamines or other vasopressors (e.g., vasopressin) is used to predict mortality $(146,147)$.

\section{Vascular Volume}

See blood volume. 


\section{Vasoplegia}

Severely low systemic vascular resistance in conjunction with profound hypotension and a normal or increased cardiac output (148). Occasionally referred to as vasoplegic shock and used synonymously with distributive shock, the vasoplegic syndrome may occur in septic shock, after surgery, burns, severe pancreatitis or extensive trauma (148).

\section{Volume Depletion}

The loss of water and electrolytes from the extracellular fluid compartment (34). Volume depletion can be classified by the location of the lost fluid, such as intracellular dehydration or extracellular fluid loss. It can also be characterized by the salt and water content of the fluid loss. Hypotonic fluid loss: A predominantly pure water deficit which is caused by water loss exceeding solute loss in the extracellular fluid, or by insufficient water intake relative to water output, leading to hypernatremic volume depletion. Hypertonic fluid loss: A deficit of water and solutes from the extracellular fluid, where the solute loss exceeds water loss, resulting in the development of hypoosmolality of the extracellular fluid and hyponatremic volume depletion. Isotonic fluid loss: A proportionate deficit of water and solutes from the extracellular fluid, therefore the osmolality of the extracellular fluid does not increase.

\section{Volume Kinetics}

The study of how water is distributed and eliminated following an infusion of intravenous fluids $(149,150)$.

\section{Volume Overload \\ See fluid overload.}

\section{Zero Balance Fluid Therapy}

A restrictive regimen aiming to avoid postoperative fluid retention (as indicated by weight gain) $(151,152)$.

\section{Routes of Fluid Administration}

Fluids are typically administered to veterinary patients through enteral, subcutaneous and intravenous routes $(23,48,153)$, or less commonly, into the medullary cavity (154) or into the coelom in reptiles (155). The ideal method of fluid delivery will vary depending on the species, the underlying disease processes, and the size of the fluid deficit. Animals that require rapid correction of life threatening conditions, such as hypovolemic shock, benefit from the rapid intravascular volume expansion achievable with intravenous fluids. On the other hand, nonintravenous fluid delivery routes, which are characterized by slower rates of absorption (156), may be sufficient in stable patients to meet maintenance fluid needs, treat lesser degrees of dehydration or keep up with abnormal ongoing losses.

Subcutaneous or enteral fluids can be considered in small animal patients with mild to moderate fluid deficits. Compared to intravenous fluid administration, there is a lower limit to the amount of fluid that can be delivered by these routes. In the presence of severe dehydration and hypovolemia, avoid fluid replacement by the subcutaneous route due to the potential for decreased absorption resulting from peripheral vasoconstriction $(7,48)$.
Where larger volumes of fluid are necessary but venous access cannot be obtained (a common dilemma in many pediatric, avian, and exotic animals), placement of an intraosseous (IO) catheter may be considered (154, 157). Despite increased resistance to flow compared to intravenous infusion, reasonably high fluid administration rates can still be achieved with intramedullary delivery (158). The gravity-dependent rate of fluid delivery was greater in the femur and humerus compared to the tibia and ilium in one canine cadaveric study (159).

When voluntary oral intake is insufficient or undesirable, fluids can be rapidly and inexpensively administered by nasogastric tube to horses $(153,160)$ and ruminants $(161,162)$ to treat mild to moderate dehydration. In some cases, parenteral methods may be preferred in camelids to reduce stress (163). As with companion animal species, intravenous fluids are preferred when severe dehydration is present due to the potential for reduced bowel absorption resulting from hypoperfusion (153).

Alternative fluid administration sites have also been described. A 6-h crystalloid infusion given per rectum was reported to be safe and well-tolerated in horses (156), although the usefulness of this technique in clinical settings remains undetermined. Unlike in reptiles, where intracoelomic fluid delivery is welldescribed (155), intraperitoneal fluid administration is rarely discussed or performed in other species (48) due the presence of safer alternatives.

\section{DISCUSSION}

Despite the frequency with which fluids are administered to veterinary patients, developing an effective fluid management plan may at times be surprisingly complex. A thorough understanding of the physiology of body fluids, fluid administration routes, therapeutic delivery strategies, risks, and complications will help to optimize patient outcomes. National and multinational organizations, such as the International Fluid Academy (IFA), provide opportunities for clinicians and researchers to promote research and education in the practice of fluid therapy. The use of clear and consistent terminology is a key component to fostering effective communication and collaboration within the veterinary and human healthcare fields.

\section{AUTHOR CONTRIBUTIONS}

The author confirms being the sole contributor of this work and has approved it for publication.

\section{FUNDING}

This work was supported by a publication fee grant from the Department of Veterinary Clinical Sciences at the University of Minnesota.

\section{ACKNOWLEDGMENTS}

I would like to thank Dr. William Muir for his helpful suggestions of terms and articles. 


\section{REFERENCES}

1. Maizel J, Airapetian N, Lorne E, Tribouilloy C, Massy Z, Slama M. Diagnosis of central hypovolemia by using passive leg raising. Intensive Care Med. (2007) 33:1133-8. doi: 10.1007/s00134-007-0642-y

2. Noel-Morgan J, Muir WW. Anesthesia-associated relative hypovolemia: mechanisms, monitoring, and treatment considerations. Front Vet Sci. (2018) 5:53. doi: 10.3389/fvets.2018.00053

3. Kamel KS, Halperin ML. Principles of acid-base physiology. In: Kamel KS, Halperin ML, editors. Fluid, Electrolyte and Acid-Base Physiology: A Problem-Based Approach. Philadelphia, PA: Elsevier, Inc. (2017). p. 3-32. doi: 10.1016/B978-0-323-35515-5.00001-4

4. Muir W. Effect of intravenously administered crystalloid solutions on acidbase balance in domestic animals. J Vet Intern Med. (2017) 31:137181. doi: $10.1111 /$ jvim. 14803

5. Shander A, Brown J, Licker M, Mazer DC, Meier J, Ozawa S, et al. Standards and best practice for acute normovolemic hemodilution: evidence-based consensus recommendations. J Cardiothorac Vasc Anesth. (2020) 34:175560. doi: 10.1053/j.jvca.2020.01.019

6. Boulpaep EL. Blood. In: Boron WF, Boulpaep EL, editors. Medical Physiology. 3rd Ed. Philadelphia, PA: Elsevier (2017). p. 429-46.

7. DiBartola Stephen P, Bateman S. Introduction to fluid therapy. In: DiBartola SP, editor. Fluid, Electrolyte, and Acid-Base Disorders in Small Animal Practice. 4th Ed. St. Louis, MO: Saunders Elsevier (2012). p. 331-50. doi: 10.1016/B978-1-4377-0654-3.00021-4

8. Torrente Artero C. A quick reference on anion gap and strong ion gap. Vet Clin North Am Small Anim Pract. (2017) 47:1916. doi: $10.1016 /$ j.cvsm.2016.10.006

9. Uchimido R, Schmidt EP, Shapiro NI. The glycocalyx: a novel diagnostic and therapeutic target in sepsis. Crit Care. (2019) 23:16. doi: 10.1186/s13054-018-2292-6

10. Cantle PM, Cotton BA. Balanced resuscitation in trauma management. Surg Clin North Am. (2017) 97:999-1014. doi: 10.1016/j.suc.2017.06.002

11. Drucker NA, Wang SK, Newton C. Pediatric trauma-related coagulopathy: balanced resuscitation, goal-directed therapy and viscoelastic assays. Semin Pediatr Surg. (2019) 28:61-6. doi: 10.1053/j.sempedsurg.2019.01.011

12. Semler MW, Kellum JA. Balanced crystalloid solutions. Am J Respir Crit Care Med. (2019) 199:952-60. doi: 10.1164/rccm.201809-1677CI

13. Guidet B, Soni N, Della Rocca G, Kozek S, Vallet B, Annane D, et al. A balanced view of balanced solutions. Crit Care. (2010) 14:325. doi: $10.1186 / \mathrm{cc} 9230$

14. Berend K. Diagnostic use of base excess in acid-base disorders. N Engl J Med. (2018) 378:1419-28. doi: 10.1056/NEJMra1711860

15. Magder S. Volume and its relationship to cardiac output and venous return. Crit Care. (2016) 20:271. doi: 10.1186/s13054-016-1438-7

16. Chow RS, Dilley P. Central venous pressure. In: Burkitt Creedon JM, Davis H, editors. Advanced Monitoring and Procedures for Small Animal Emergency and Critical Care. Hoboken, NJ: Wiley-Blackwell (2012). p. 145-58. doi: 10.1002/9781118997246.ch11

17. Marik PE, Cavallazzi R. Does the central venous pressure predict fluid responsiveness? An updated meta-analysis and a plea for some common sense. Crit Care Med. (2013) 41:177481. doi: 10.1097/CCM.0b013e31828a25fd

18. Hahn RG, He R, Li Y. Central venous pressure as an adjunct to flow-guided volume optimisation after induction of general anaesthesia. Anaesthesiol Intensive Ther. (2016) 48:110-5. doi: 10.5603/AIT.a2015.0066

19. Hammel H. Colligative properties of a solution. Science. (1976) 192:74856. doi: 10.1126/science. 1265478

20. Vujovic P, Chirillo M, Silverthorn DU. Learning (by) osmosis: an approach to teaching osmolarity and tonicity. Gen Educ Res. (2018) 42:62635. doi: 10.1152/advan.00094.2018

21. Byers CG. Fluid therapy: options and rational selection. Vet Clin North Am Small Anim Pract. (2017) 47:359-71. doi: 10.1016/j.cvsm.2016.09.007

22. Bevan DR. Colloid osmotic pressure. Anaesthesia. (1980) 35:263-70. doi: 10.1111/j.1365-2044.1980.tb05094.x

23. Davis H, Jensen T, Johnson A, Knowles $\mathrm{P}$, Meyer R, Rucinsky R, et al. 2013 AAHA/AAFP Fluid Therapy Guidelines for Dogs and Cats. (2013). Available online at: https://www.aaha.org/globalassets/02-guidelines/fluidtherapy/fluidtherapy_guidlines_toolkit.pdf (accessed July 21, 2020).
24. Edwards MR, Mythen MG. Fluid therapy in critical illness. Extrem Physiol Med. (2014) 3:16. doi: 10.1186/2046-7648-3-16

25. Rudloff E, Kirby R. Colloids: current recommendations. In: Bonagura JD, editor. Kirk's Current Veterinary Therapy XIII. Philadelphia, PA: WB Saunders Company (2000). p. 131-6.

26. Woodcock T. The Colloid Delusion. (2015). Available online at: https:// fluidphysiology.org/the-colloid-delusion/ (accessed November 15, 2020).

27. Macintire DK, Drobatz KJ, Haskins SC, Saxon WD. Appendix E: Constant Rate Infusions. In: Macintire DK, Drobatz KJ, Haskins SC, Saxon WD, editors. Manual of Small Animal Emergency and Critical Care Medicine. 2nd ed. Ames, IA: Wiley-Blackwell (2012). doi: 10.1002/97811194 21870

28. Hiebl B, Mrowietz C, Ploetze K, Matschke K, Jung F. Critical hematocrit and oxygen partial pressure in the beating heart of pigs. Microvasc Res. (2010) 80:389-93. doi: 10.1016/j.mvr.2010.06.002

29. Kemming GI, Meisner FG, Kleen M, Meier JM, Tillmanns J, Hutter JW, et al. Hyperoxic ventilation at the critical haematocrit. Resuscitation. (2003) 56:289-97. doi: 10.1016/S0300-9572(02)00408-2

30. Claure-Del Granado R, Mehta RL. Fluid overload in the ICU: evaluation and management. BMC Nephrol. (2016) 17:109. doi: 10.1186/s12882-0160323-6

31. Hoste EA, Maitland K, Brudney CS, Mehta R, Vincent JL, Yates D, et al. Four phases of intravenous fluid therapy: a conceptual model. Br J Anaesth. (2014) 113:740-7. doi: 10.1093/bja/aeu300

32. Bogert JN, Harvin JA, Cotton BA. Damage control resuscitation. J Intensive Care Med. (2016) 31:177-86. doi: 10.1177/0885066614558018

33. Giannoudi M, Harwood P. Damage control resuscitation: lessons learned. Eur J Trauma Emerg Surg. (2016) 42:27382. doi: 10.1007/s00068-015-0628-3

34. Asim M, Alkadi MM, Asim H, Ghaffar A. Dehydration and volume depletion: how to handle the misconceptions. World J Nephrol. (2019) 8:23-32. doi: $10.5527 /$ win.v8.i1.23

35. NICE Clinical Guidelines, No. 174, National Clinical Guideline Center (UK). Intravenous fluid therapy: intravenous fluid therapy in adults in hospital. London: Royal College of Physicians. (2013). Available online at: https://www. nice.org.uk/guidance/cg174 (accessed October 14, 2020).

36. Thomas DR, Cote TR, Lawhorne L, Levenson SA, Rubenstein LZ, Smith DA, et al. Understanding clinical dehydration and its treatment. J Am Med Dir Assoc. (2008) 9:292-301. doi: 10.1016/j.jamda.2008.03.006

37. Silversides JA, Fitzgerald E, Manickavasagam US, Lapinsky SE, Nisenbaum $\mathrm{R}$, Hemmings N, et al. Deresuscitation of patients with iatrogenic fluid overload is associated with reduced mortality in critical illness. Crit Care Med. (2018) 46:1600-7. doi: 10.1097/CCM.0000000000003276

38. Silversides JA, Perner A, Malbrain MLNG. Liberal versus restrictive fluid therapy in critically ill patients. Intensive Care Med. (2019) 45:14402. doi: 10.1007/s00134-019-05713-y

39. Rivers E, Nguyen B, Havstad S, Ressler J, Muzzin A, Knoblich B, et al. Early goal-directed therapy in the treatment of severe sepsis and septic shock. $N$ Engl J Med. (2001) 345:1368-77. doi: 10.1056/NEJMoa010307

40. Chong MA, Wang Y, Berbenetz NM, McConachie I. Does goal-directed haemodynamic and fluid therapy improve peri-operative outcomes? Eur J Anaesthesiol. (2018) 35:469-83. doi: 10.1097/EJA.0000000000000778

41. Emmet M, Seldin DW. The pathophysiology of edema formation: general concepts. In: Seldin D, Giebisch G, editors. Diuretic Agents: Clinical Physiology and Pharmacology. San Diego: Academic Press (1997). p. 345-58. doi: 10.1016/B978-012635690-8/50018-9

42. Scallan J, Huxley VH, Korthuis RJ. Pathophysiology of edema formation. In: Scallan J, Huxley VH, Korthuis RJ, editors. Capillary Fluid Exchange: Regulation, Functions, Pathology. San Rafael, CA: Morgan \& Claypool Life Sciences (2010)

43. Bhave G, Neilson EG. Body fluid dynamics: back to the future. J Am Soc Nephrol. (2011) 22:2166-81. doi: 10.1681/ASN.2011080865

44. Woodcock TE, Woodcock TM. Revised starling equation and the glycocalyx model of transvascular fluid exchange: an improved paradigm for prescribing intravenous fluid therapy. Br J Anaesth. (2012) 108:38494. doi: 10.1093/bja/aer515

45. Gaudette S, Hughes D, Boller M. The endothelial glycocalyx: structure and function in health and critical illness. J Vet Emerg Crit Care. (2020) 30:117-34. doi: 10.1111/vec.12925 
46. Johansson PI, Stensballe J, Ostrowski SR. Shock induced endotheliopathy (SHINE) in acute critical illness - a unifying pathophysiologic mechanism. Crit Care. (2017) 21:25. doi: 10.1186/s13054-017-1605-5

47. van der Jagt M. Fluid management of the neurological patient: a concise review. Crit Care. (2016) 20:126. doi: 10.1186/s13054-016-1309-2

48. Mensack S. Fluid therapy: options and rational administration. Vet Clin North Am Small Anim Pract. (2008) 38:57586. doi: 10.1016/j.cvsm.2008.01.028

49. Neyra JA, Li X, Canepa-Escaro F, Adams-Huet B, Toto RD, Yee J, et al. Cumulative fluid balance and mortality in septic patients with or without acute kidney injury and chronic kidney disease. Crit Care Med. (2016) 44:1891-900. doi: 10.1097/CCM.0000000000001835

50. Oh T, Hwang J-W, Jeon Y-T, Do S-H. Perioperative cumulative fluid balance and its association with an increase in costs after major surgery. J Clin Med. (2018) 7:227. doi: 10.3390/jcm7090227

51. Cherpanath TGV, Aarts LPHJ, Groeneveld JAB, Geerts BF. Defining fluid responsiveness: a guide to patient-tailored volume titration. J Cardiothorac Vasc Anesth. (2014) 28:745-54. doi: 10.1053/j.jvca.2013.12.025

52. Martin GS, Kaufman DA, Marik PE, Shapiro NI, Levett DZH, Whittle J, et al. Perioperative Quality Initiative (POQI) consensus statement on fundamental concepts in perioperative fluid management: fluid responsiveness and venous capacitance. Perioper Med. (2020) 9:12. doi: 10.1186/s13741-020-00142-8

53. Glassford NJ, Mårtensson J, Eastwood GM, Jones SL, Tanaka A, Wilkman E, et al. Defining the characteristics and expectations of fluid bolus therapy: a worldwide perspective. J Crit Care. (2016) 35:12632. doi: 10.1016/j.jcrc.2016.05.017

54. Toscani L, Aya HD, Antonakaki D, Bastoni D, Watson X, Arulkumaran N, et al. What is the impact of the fluid challenge technique on diagnosis of fluid responsiveness? A systematic review and meta-analysis. Crit Care. (2017) 21:207. doi: 10.1186/s13054-017-1796-9

55. Wellman ML, DiBartola SP, Kohn CW. Applied physiology of body fluids in dogs and cats. In: DiBartola SP, editor. Fluid, Electrolyte, and Acid-Base Disorders in Small Animal Practice. 4th Ed. St. Louis, MO: Saunders Elsevier (2012). p. 2-5.

56. Saffle JR. The phenomenon of "fluid creep" in acute burn resuscitation. $J$ Burn Care Res. (2007) 28:382-95. doi: 10.1097/BCR.0B013E318053D3A1

57. Cartotto R, Greenhalgh DG, Cancio C. Burn state of the science: fluid resuscitation. J Burn Care Res. (2017) 38:e596604. doi: 10.1097/BCR.0000000000000541

58. Van Regenmortel N, Verbrugghe W, Roelant E, Van den Wyngaert T, Jorens PG. Maintenance fluid therapy and fluid creep impose more significant fluid, sodium, and chloride burdens than resuscitation fluids in critically ill patients: a retrospective study in a tertiary mixed ICU population. Intensive Care Med. (2018) 44:409-17. doi: 10.1007/s00134-018-5147-3

59. Cavanagh AA, Sullivan LA, Hansen BD. Retrospective evaluation of fluid overload and relationship to outcome in critically ill dogs. J Vet Emerg Crit Care. (2016) 26:578-86. doi: 10.1111/vec.12477

60. Thomovsky E, Brooks A, Johnson P. Fluid overload in small animal patients. Top Companion Anim Med. (2016) 31:94-9. doi: 10.1053/j.tcam.2016.08.007

61. Vincent JL, Pinsky MR. We should avoid the term "fluid overload." Crit Care. (2018) 22:214. doi: 10.1186/s13054-018-2141-7

62. Kattan E, Ospina-Tascón GA, Teboul JL, Castro R, Cecconi M, Ferri G, et al. Systematic assessment of fluid responsiveness during early septic shock resuscitation: secondary analysis of the ANDROMEDA-SHOCK trial. Crit Care. (2020) 24:23. doi: 10.1186/s13054-020-2732-y

63. Pinsky MR, Payen D. Functional hemodynamic monitoring. Crit Care. (2005) 9:566-72. doi: 10.1186/cc3927

64. Mottelson MN, Lundsgaard CC, Møller S. Mechanisms in fluid retention - towards a mutual concept. Clin Physiol Funct Imaging. (2020) 40:6775. doi: $10.1111 / \mathrm{cpf} .12615$

65. Hahn RG, Bahlmann H, Nilsson L. Preoperative fluid retention increases blood loss during major open abdominal surgery. Perioper Med. (2017) 6:12. doi: 10.1186/s13741-017-0068-1

66. Nesto RW, Bell D, Bonow RO, Fonseca V, Grundy SM, Horton ES, et al. Thiazolidinedione use, fluid retention, and congestive heart failure: a consensus statement from the American Heart Association and American Diabetes Association. Diabetes Care. (2004) 27:25663. doi: $10.2337 /$ diacare.27.1.256

67. Wednler R. Fluid overload and underload. In: Chandraharan E, Arulkumaran S, editors. Obstetric and Intrapartum Emergencies. Cambridge; New York, NY: Cambridge University Press (2012). p. 221-6.

68. O’Neal JB, Shaw AD. Goal-directed therapy: what we know and what we need to know. Perioper Med. (2015) 4:1. doi: 10.1186/s13741-015-0012-1

69. O'Neal JB, Shaw AD. Goal-directed therapy in the operating room: is there any benefit? Curr Opin Anaesthesiol. (2016) 29:80-4. doi: 10.1097/ACO.0000000000000273

70. Ince $\mathrm{C}$. Hemodynamic coherence and the rationale for monitoring the microcirculation. Crit Care. (2015) 19:38. doi: 10.1186/cc14726

71. Arnemann P, Seidel L, Ertmer C. Haemodynamic coherence - The relevance of fluid therapy. Best Pract Res Clin Anaesthesiol. (2016) 30:41927. doi: 10.1016/j.bpa.2016.11.003

72. Meng F, Kassa T, Jana S, Wood F, Zhang X, Jia Y, et al. Comprehensive biochemical and biophysical characterization of hemoglobin-based oxygen carrier therapeutics: all HBOCs are not created equally. Bioconjug Chem. (2018) 29:1560-75. doi: 10.1021/acs.bioconjchem.8b00093

73. Sen Gupta A. Hemoglobin-based oxygen carriers: current state-of-the-art and novel molecules. Shock. (2019) 52:7083. doi: 10.1097/SHK.0000000000001009

74. Jahr JS, Guinn NR, Lowery DR, Shore-Lesserson L, Shander A. Blood substitutes and oxygen therapeutics: a review. Anesth Analg. (2019). doi: 10.1213/ANE.0000000000003957. [Epub ahead of print].

75. Barker ME. 0.9\% saline induced hyperchloremic acidosis. J Trauma Nurs. (2015) 22:111-6. doi: 10.1097/JTN.0000000000000115

76. Mendes RDS, Oliveira M V., Padilha GA, Rocha NN, Santos CL, Maia LA, et al. Effects of crystalloid, hyper-oncotic albumin, and iso-oncotic albumin on lung and kidney damage in experimental acute lung injury. Respir Res. (2019) 20:155. doi: 10.1186/s12931-019-1115-x

77. Strandvik GF. Hypertonic saline in critical care: a review of the literature and guidelines for use in hypotensive states and raised intracranial pressure. Anaesthesia. (2009) 64:990-1003. doi: 10.1111/j.1365-2044.2009.0 5986.x

78. Fatima N, Ayyad A, Shuaib A, Saqqur M. Hypertonic solutions in traumatic brain injury: a systematic review and meta-analysis. Asian J Neurosurg. (2019) 14:382. doi: 10.4103/ajns.AJNS_8_19

79. Schroth M, Plank C, Meissner U, Eberle KP, Weyand M, Cesnjevar R, et al. Hypertonic-hyperoncotic solutions improve cardiac function in children after open-heart surgery. Pediatrics. (2006) 118:e76-84. doi: 10.1542/ peds.2005-2795

80. García-Martínez D, Portilla-De Buen E, Leal C, Santillán P, Muñiz J. The immediate response to severe shock in a canine model with a combination of hypertonic-hyperoncotic solution with naloxone. Shock. (2006) 26:3795. doi: 10.1097/01.shk.0000226339.48033.8b

81. Ponikowski P, Voors AA, Anker SD, Bueno H, Cleland JGF, Coats AJS, et al. 2016 ESC Guidelines for the diagnosis and treatment of acute and chronic heart failure. Eur J Heart Fail. (2016) 18:891-975. doi: 10.1002/ejhf.592

82. van Diepen S, Katz JN, Albert NM, Henry TD, Jacobs AK, Kapur NK, et al. Contemporary management of cardiogenic shock: a scientific statement from the American Heart Association. Circulation. (2017) 136:e23268. doi: 10.1161/CIR.0000000000000525

83. Van Der Mullen J, Wise R, Vermeulen G, Moonen PJ, Malbrain MLNG. Assessment of hypovolaemia in the critically ill. Anaesthesiol Intensive Ther. (2018) 50:150-9. doi: 10.5603/AIT.a2017.0077

84. Reinhart JM, Yancey MR, Girard-Denton JD, Schermerhorn T. Determination of tonicity effects of ketoacids and lactate by use of two canine red blood cell assays. Am J Vet Res. (2015) 76:77-83. doi: 10.2460/ajvr.76.1.77

85. Lulich JP, Osborne CA. Quantitative urine collection as an aid to diagnosis therapy. In: Bonagura JD, editor. Kirk's Current Veterinary Therapy XIII. Philadelphia, PA: WB Saunders Co. (2000). p. 12-7.

86. Hansen B, Vigani A. Maintenance fluid therapy: isotonic versus hypotonic solutions. Vet Clin North Am Small Anim Pract. (2017) 47:38395. doi: 10.1016/j.cvsm.2016.10.001

87. Mange K, Matsuura D, Cizman B, Soto H, Ziyadeh FN, Goldfarb $S$, et al. Language guiding therapy: the case of 
dehydration versus volume depletion. Ann Intern Med. (1997) 127:848-53. doi: 10.7326/0003-4819-127-9-199711010-00020

88. Wiedermann CJ, Dunzendorfer S, Gaioni LU, Zaraca F, Joannidis M. Hyperoncotic colloids and acute kidney injury: a meta-analysis of randomized trials. Crit Care. (2010) 14:R191. doi: 10.1186/cc9308

89. Zhou F, Cove M, Peng Z, Bishop J, Singbartl K, Kellum J. Normal saline resuscitation worsens lactic acidosis in experimental sepsis. Crit Care. (2012) 16:P253. doi: 10.1186/cc10860

90. Suetrong B, Walley KR. Lactic acidosis in sepsis: it's not all anaerobic: implications for diagnosis and management. Chest. (2016) 149:25261. doi: 10.1378/chest.15-1703

91. Rosenstein PG, Tennent-Brown BS, Hughes D. Clinical use of plasma lactate concentration. Part 1: physiology, pathophysiology, and measurement. J Vet Emerg Crit Care. (2018) 28:85-105. doi: 10.1111/vec.12708

92. Kamel KS, Oh MS, Halperin ML. L-lactic acidosis: pathophysiology, classification, and causes; emphasis on biochemical and metabolic basis. Kidney Int. (2020) 97:75-88. doi: 10.1016/j.kint.2019.08.023

93. Boysen SR, Dorval P. Effects of rapid intravenous 100\% L-isomer lactated Ringer's administration on plasma lactate concentrations in healthy dogs. J Vet Emerg Crit Care. (2014) 24:571-7. doi: 10.1111/vec. 12213

94. Brooks D, Churchill J, Fein K, Linder D, Michel KE, Tudor K, et al. 2014 AAHA weight management guidelines for dogs and cats. J Am Anim Hosp Assoc. (2014) 50:1-11. doi: 10.5326/JAAHA-MS-6331

95. Myles PS, Bellomo R, Corcoran T, Forbes A, Peyton P, Story D, et al. Restrictive versus liberal fluid therapy for major abdominal surgery. $N$ Engl $J$ Med. (2018) 378:2263-74. doi: 10.1056/NEJMoa1801601

96. Myles PS, McIlroy DR, Bellomo R, Wallace S. Importance of intraoperative oliguria during major abdominal surgery: findings of the restrictive versus liberal fluid therapy in major abdominal surgery trial. Br J Anaesth. (2019) 122:726-33. doi: 10.1016/j.bja.2019.01.010

97. Bundgaard-Nielsen M, Secher NH, Kehlet H. 'Liberal' vs. 'restrictive' perioperative fluid therapy - a critical assessment of the evidence. Acta Anaesthesiol Scand. (2009) 53:843-51. doi: 10.1111/j.1399-6576.2009.02029.x

98. Feihl F, Liaudet L, Waeber B. The macrocirculation and microcirculation of hypertension. Curr Hypertens Rep. (2009) 11:182-9. doi: 10.1007/s11906-009-0033-6

99. Llau JV, Acosta FJ, Escolar G, Fernández-Mondéjar E, Guasch E, Marco P, et al. Multidisciplinary consensus document on the management of massive haemorrhage (HEMOMAS document). Med Intensiva. (2015) 39:483504. doi: 10.1016/j.medine.2015.10.001

100. Jutkowitz LA, Rozanski EA, Moreau JA, Rush JE. Massive transfusion in dogs: 15 cases (1997-2001). J Am Vet Med Assoc. (2002) 220:16649. doi: 10.2460 /javma.2002.220.1664

101. Holcomb JB, Tilley BC, Baraniuk S, Fox EE, Wade CE, Podbielski JM, et al. Transfusion of plasma, platelets, and red blood cells in a 1:1:1 vs a 1:1:2 ratio and mortality in patients with severe trauma: the PROPPR randomized clinical trial. JAMA. (2015) 313:471-82. doi: 10.1001/jama.2015.12

102. Levy BI, Ambrosio G, Pries AR, Struijker-Boudier HAJ. Microcirculation in hypertension: a new target for treatment? Circulation. (2001) 104:73540. doi: $10.1161 / \mathrm{hc} 3101.091158$

103. Kieffer PJ, Williams JM, Shepard MK, Giguere S, Epstein KL. Comparison of the oral and rectal mucosal and colonic serosal microcirculations of healthy, anesthetized horses. Can J Vet Res. (2018) 82:55-9.

104. Gommeren K, Allerton FJ, Morin E, Reynaud A, Peeters D, Silverstein DC. Evaluation of a rapid bedside scoring system for microcirculation videos acquired from dogs. J Vet Emerg Crit Care. (2014) 24:55461. doi: $10.1111 /$ vec. 12212

105. Lacey J, Corbett J, Forni L, Hooper L, Hughes F, Minto G, et al. A multidisciplinary consensus on dehydration: definitions, diagnostic methods and clinical implications. Ann Med. (2019) 51:232-51. doi: 10.1080/07853890.2019.1628352

106. Erstad BL. Osmolality and osmolarity: narrowing the terminology gap. Pharmacotherapy. (2003) 23:1085-6. doi: 10.1592/phco.23.10.1085.32751

107. Carr EA. Enteral/parenteral nutrition in foals and adult horses practical guidelines for the practitioner. Vet Clin North Am Equine Pract. (2018) 34:169-80. doi: 10.1016/j.cveq.2017.11.012
108. Theron A, Bodger O, Williams D. Comparison of three techniques using the Parkland formula to aid fluid resuscitation in adult burns. Emerg Med J. (2014) 31:730-5. doi: 10.1136/emermed-2013-202652

109. Vincent JL, De Backer D. Circulatory shock. N Engl J Med. (2013) 369:172634. doi: 10.1056/NEJMra1208943

110. Michael Peters A. The precise physiological definition of tissue perfusion and clearance measured from imaging. Eur J Nucl Med Mol Imaging. (2018) 45:1139-41. doi: 10.1007/s00259-018-3982-7

111. Duchesne JC, Kaplan LJ, Balogh ZJ, Malbrain MLNG. Role of permissive hypotension, hypertonic resuscitation and the global increased permeability syndrome in patients with severe haemorrhage: adjuncts to damage control resuscitation to prevent intra-abdominal hypertension. Anaesthesiol Intensive Ther. (2015) 47:143-55. doi: 10.5603/AIT.a2014.0052

112. Stockham SL, Scott MA. Fundamentals of Veterinary Clinical Pathology. 2nd ed. Ames, IA: Blackwell Publishing (2008).

113. Cannesson M, Desebbe O, Rosamel P, Delannoy B, Robin J, Bastien O, et al. Pleth variability index to monitor the respiratory variations in the pulse oximeter plethysmographic waveform amplitude and predict fluid responsiveness in the operating theatre. Br J Anaesth. (2008) 101:2006. doi: 10.1093/bja/aen133

114. Woodcock T. Protein vs. proteid - what's the difference? WikiDiff. (2015). Available online at: https://wikidiff.com/protein/proteid (accessed October 14, 2020).

115. Pareek M, Vaduganathan M, Biering-Sørensen T, Byrne C, Qamar A, Almarzooq Z, et al. Pulse pressure, cardiovascular events, and intensive blood-pressure lowering in the systolic blood pressure intervention trial (SPRINT). Am J Med. (2019) 132:733-9. doi: 10.1016/j.amjmed.2019.01.001

116. Sano H, Seo J, Wightman P, Cave NJ, Gieseg MA, Johnson CB, et al. Evaluation of pulse pressure variation and pleth variability index to predict fluid responsiveness in mechanically ventilated isoflurane-anesthetized dogs. $J$ Vet Emerg Crit Care. (2018) 28:301-9. doi: 10.1111/vec.12728

117. Sano H, Fujiyama M, Wightman P, Cave NJ, Gieseg MA, Johnson CB, et al. Investigation of percentage changes in pulse wave transit time induced by mini-fluid challenges to predict fluid responsiveness in ventilated dogs. J Vet Emerg Crit Care. (2019) 29:391-8. doi: 10.1111/vec.12860

118. Ji L, Liu C, Li P, Wang X, Liu C, Hou Y. Increased pulse wave transit time after percutaneous coronary intervention procedure in CAD patients. Sci Rep. (2018) 8:115. doi: 10.1038/s41598-017-18520-6

119. Sano H, Chambers JP. Ability of pulse wave transit time to detect changes in stroke volume and to estimate cardiac output compared to thermodilution technique in isoflurane-anaesthetised dogs. Vet Anaesth Analg. (2017) 44:1057-67. doi: 10.1016/j.vaa.2016.11.014

120. Hahn RG, Drobin D, Li Y, Zdolsek J. Kinetics of Ringer's solution in extracellular dehydration and hemorrhage. Shock. (2020) 53:56673. doi: 10.1097/SHK.0000000000001422

121. Malbrain MLNG, van Regenmortel N, Saugel B, de Tavernier B, Van Gaal PJ, Joannes-Boyau O, et al. Principles of fluid management and stewardship in septic shock: it is time to consider the four D's and the four phases of fluid therapy. Ann Intensive Care. (2018) 8:66. doi: 10.1186/s13613-018-0402-x

122. Erstad BL. The revised starling equation: the debate of albumin versus crystalloids continues. Ann Pharmacother. (2020) 54:921-7. doi: 10.1177/1060028020907084

123. Michel CC, Woodcock TE, Curry FRE. Understanding and extending the Starling principle. Acta Anaesthesiol Scand. (2020) 64:1032-7. doi: 10.1111/aas.13603

124. Cecconi M, de Backer D, Antonelli M, Beale R, Bakker J, Hofer C, et al. Consensus on circulatory shock and hemodynamic monitoring. Task force of the European Society of Intensive Care Medicine. Intensive Care Med. (2014) 40:1795-815. doi: 10.1007/s00134-014-3525-z

125. Millham FH. A brief history of shock. Surgery. (2010) 148:102637. doi: 10.1016/j.surg.2010.02.014

126. Bellumkonda L, Gul B, Masri SC. Evolving concepts in diagnosis and management of cardiogenic shock. Am J Cardiol. (2018) 122:110410. doi: 10.1016/j.amjcard.2018.05.040

127. McGowan EE, Marryott K, Drobatz KJ, Reineke EL. Evaluation of the use of shock index in identifying acute blood loss in healthy blood donor dogs. J Vet Emerg Crit Care. (2017) 27:524-31. doi: 10.1111/vec.12640 
128. Koch E, Lovett S, Nghiem T, Riggs R, Rech MA. Shock index in the emergency department: utility and limitations. Open Access Emerg Med. (2019) 11:179-99. doi: 10.2147/OAEM.S178358

129. Dorrington KL. Skin turgor: do we understand the clinical sign? Lancet. (1981) 1:264-5. doi: 10.1016/S0140-6736(81)92097-3

130. Goucher TK, Hartzell AM, Seales TS, Anmuth AS, Zanghi Brian M., Otto CM. Evaluation of skin turgor and capillary refill time as predictors of dehydration in exercising dogs. Am J Vet Res. (2019) 80:1238. doi: 10.2460/ajvr.80.2.123

131. Story DA. Bench-to-bedside review: a brief history of clinical acid-base. Crit Care. (2004) 8:253-8. doi: 10.1186/cc2861

132. Gelman S, Warner DS, Warner MA. Venous function and central venous pressure. Anesthesiology. (2008) 108:73548. doi: 10.1097/ALN.0b013e3181672607

133. Li C, Lin FQ, Fu SK, Chen GQ, Yang XH, Zhu CY, et al. Stroke volume variation for prediction of fluid responsiveness in patients undergoing gastrointestinal surgery. Int J Med Sci. (2013) 10:14855. doi: 10.7150/ijms.5293

134. Russell KE, Hansen BD, Stevens JB. Strong ion difference approach to acid-base imbalances with clinical applications to dogs and cats. Vet Clin North Am Small Anim Pract. (1996) 26:1185-201. doi: 10.1016/S0195-5616(96)50061-6

135. Constable PD. Clinical assessment of acid-base status. Vet Clin North Am Food Anim Pract. (1999) 15:447-71. doi: 10.1016/S0749-0720(15)30158-4

136. Hopper K, Epstein SE, Kass PH, Mellema MS. Evaluation of acid-base disorders in dogs and cats presenting to an emergency room. Part 2: Comparison of anion gap, strong ion gap, and semiquantitative analysis. $J$ Vet Emerg Crit Care. (2014) 24:502-8. doi: 10.1111/vec.12214

137. Morgan TJ. The Stewart approach - one clinician's perspective. Clin Biochem Rev. (2009) 30:41-54. Available online at: www.acidbase.org

138. Frost EA. The rise and fall of the third space: appropriate intraoperative fluid management. J Med Assoc Thai. (2013) 96:1001-8.

139. Jacob M, Chappell D, Rehm M. The "third space" - fact or fiction? Best Pract Res Clin Anaesthesiol. (2009) 23:145-57. doi: 10.1016/j.bpa.2009.05.001

140. Chappell D, Jacob M, Hofmann-Kiefer K, Conzen P, Rehm M. A rational approach to perioperative fluid management. Anesthesiology. (2008) 109:723-63. doi: 10.1097/ALN.0b013e3181863117

141. Pachtinger G. Hypovolemic shock. Clin Br. (2014) 13-6.

142. Schermerhorn T, Barr SC. Relationships between glucose, sodium and effective osmolality in diabetic dogs and cats. J Vet Emerg Crit Care. (2006) 16:19-24. doi: 10.1111/j.1476-4431.2005.00161.x

143. Bhave G, Neilson EG. Volume depletion versus dehydration: how understanding the difference can guide therapy. Am J Kidney Dis. (2011) 58:302-9. doi: 10.1053/j.ajkd.2011.02.395

144. Barbee RW, Reynolds PS, Ward KR. Assessing shock resuscitation strategies by oxygen debt repayment. Shock. (2010) 33:11322. doi: 10.1097/SHK.0b013e3181b8569d

145. Brinkmann L, Gerken M, Riek A. Seasonal changes of total body water and water intake in Shetland ponies measured by an isotope dilution technique 1. J Anim Sci. (2013) 91:3750-8. doi: 10.2527/jas.2012-5317

146. Levy B, Collin S, Sennoun N, Ducrocq N, Kimmoun A, Asfar P, et al. Vascular hyporesponsiveness to vasopressors in septic shock: from bench to bedside. Intensive Care Med. (2010) 36:2019-29. doi: 10.1007/s00134-010-2045-8

147. Lee EP, Zhao LL, Hsia SH, Chan OW, Lin CY, Su YT, et al. Vascular reactivity index as an effective predictor of mortality in children with refractory septic shock. J Intensive Care Med. (2020) 885066620914850. doi: 10.1177/0885066620914850. [Epub ahead of print].
148. Lambden S, Creagh-Brown BC, Hunt J, Summers C, Forni LG. Definitions and pathophysiology of vasoplegic shock. Crit Care. (2018) 22:174. doi: 10.1186/s13054-018-2102-1

149. Hahn RG. Understanding volume kinetics. Acta Anaesthesiol Scand. (2020) 64:570-8. doi: 10.1111/aas.13533

150. Yi JM, Bang JY, Choi B, Cho C, Lee YH, Lee EK, et al. Population-based volume kinetics of crystalloids and colloids in healthy volunteers. Sci Rep. (2019) 9:18638. doi: 10.1038/s41598-019-55171-1

151. Brandstrup B, Svendsen PE, Rasmussen M, Belhage B, Rodt SÅ, Hansen B, et al. Which goal for fluid therapy during colorectal surgery is followed by the best outcome: near-maximal stroke volume or zero fluid balance? $\mathrm{Br}$ Anaesth. (2012) 109:191-9. doi: 10.1093/bja/aes163

152. Voldby AW, Brandstrup B. Fluid therapy in the perioperative setting-A clinical review. J Intensive Care. (2016) 4:27. doi: 10.1186/s40560-016-0154-3

153. Schott HC. Fluid therapy: a primer for students, technicians, and veterinarians in equine practice. Vet Clin North Am Equine Pract. (2006) 22:1-14. doi: 10.1016/j.cveq.2005.12.021

154. Lee JA, Cohn LA. Fluid therapy for pediatric patients. Vet Clin North Am Small Anim Pract. (2017) 47:373-82. doi: 10.1016/j.cvsm.2016.09.010

155. Camacho M, Del Pino Quintana M, Calabuig P, Luzardo OP, Boada LD, Zumbado $\mathrm{M}$, et al. Acid-base and plasma biochemical changes using crystalloid fluids in stranded juvenile loggerhead sea turtles (Caretta caretta). PLoS ONE. (2015) 10:e0132217. doi: 10.1371/journal.pone.01 32217

156. Khan A, Hallowell GD, Underwood C, van Eps AW. Continuous fluid infusion per rectum compared with intravenous and nasogastric fluid administration in horses. Equine Vet J. (2019) 51:767-73. doi: 10.1111/evj.13113

157. Gonzales K. Periparturient diseases in the Dam. Vet Clin North Am Small Anim Pract. (2018) 48:663-81. doi: 10.1016/j.cvsm.2018.02.010

158. Salhanick MA, Sams VG, Pidcoke HF, Fedyk CG, Scherer MR, Dubick $\mathrm{MA}$, et al. Shed pleural blood from traumatic hemothorax contains elevated levels of pro-inflammatory cytokines. Shock. (2016) 46:1448. doi: 10.1097/SHK.0000000000000609

159. Lange J, Boysen SR, Bentley A, Atilla A. Intraosseous catheter flow rates and ease of placement at various sites in canine cadavers. Front Vet Sci. (2019) 6:312. doi: $10.3389 /$ fvets.2019.00312

160. Sosa Leon LA. Treatment of exercise-induced dehydration. Vet Clin North Am Equine Pract. (1998) 14:159-73. doi: 10.1016/S0749-0739(17)30218-3

161. Constable P. Fluid and electrolyte therapy in ruminants. Vet Clin North Am Food Anim Pract. (2003) 19:557-97. doi: 10.1016/S0749-0720(03)00054-9

162. Roussel AJ. Fluid therapy in mature cattle. Vet Clin North Am Food Anim Pract. (1990) 6:111-23. doi: 10.1016/S0749-0720(15)30898-7

163. Jones $M$, Navarre C. Fluid therapy in small ruminants and camelids. Vet Clin North Am Food Anim Pract. (2014) 30:44153. doi: 10.1016/j.cvfa.2014.04.006

Conflict of Interest: The author declares that the research was conducted in the absence of any commercial or financial relationships that could be construed as a potential conflict of interest.

Copyright (C) 2021 Chow. This is an open-access article distributed under the terms of the Creative Commons Attribution License (CC BY). The use, distribution or reproduction in other forums is permitted, provided the original author(s) and the copyright owner(s) are credited and that the original publication in this journal is cited, in accordance with accepted academic practice. No use, distribution or reproduction is permitted which does not comply with these terms. 